\title{
Usulan Strategi Pemasaran bagi CDCmodels untuk Memenangkan Persaingan Onlineshop
}

\author{
Marketing Strategy Proposal for CDCmodels to Win Onlineshop Competition
}

\author{
Christine Dwi Herlinmanda, Yulianti \\ Program Studi Teknik Industri, Fakultas Teknik Universitas Kristen Maranatha, Bandung \\ E-mail: christinedwih@yahoo.com, yulianti@eng.maranatha.edu
}

\begin{abstract}
Abstrak
CDCmodels merupakan onlinestore pakaian yang berdiri pada Desember 2012. Selama tahun 2013, CDCmodels mengalami peningkatan penjualan namun ketatnya persaingan menyebabkan penurunan penjualan mulai Februari 2014, hingga CDCmodels tidak mampu lagi mencapai target penjualannya.

Pengumpulan data dilakukan dengan cara menyebarkan kuesioner yang mengacu pada model bauran pemasaran 4P untuk E-commerce \& E-business dan teori segmentasi-targetingpositioning. Kuesioner penelitian disebarkan melalui email pada konsumen CDCmodels dan onlineshop pakaian lain.

Setelah data yang diperoleh dari kuesioner terbukti valid dan reliabel, data peringkat antara CDCmodels dan onlineshop pakaian lain diolah menggunakan metode Corresspondence Analysis. Pengukuran tingkat kepuasan konsumen terhadap CDCmodels menggunakan pengujian hipotesis rata-rata dua populasi independen, dengan data tingkat kepentingan konsumen akan onlineshop pakaian dan tingkat kinerja CDCmodels. Data tingkat kepentingan dan kinerja tersebut juga diolah dengan menggunakan metode Importance-Performance Analysis (IPA). Profil konsumen digunakan untuk menentukan targeting dan positioning yang tepat bagi CDCmodels, dan melengkapi usulan perbaikan bagi CDCmodels.
\end{abstract}

Prioritas strategi pemasaran yang harus dilakukan oleh CDCmodels berdasarkan gabungan hasil pengolahan Corresspondence Analysis, pengujian hipotesis rata-rata dan ImportancePerformance Analysis. Penelitian ini juga mengusulkan rancangan website bagi CDCmodels.

Kata kunci: bauran pemasaran, e-commerce dan e-business, corresspondence analysis, pengujian hipotesis, importance-performance analysis.

\begin{abstract}
CDCmodels is an onlinestore outfit that stood in December 2012. During the year 2013, CDCmodels experienced increased sales but tight competition led to a decrease in sales starting February 2014, until CDCmodels no longer able to achieve sales targets.

Data collected by distributing questionnaires that refer to 4P Marketing Mix model for Ecommerce \& E-business and segmentation-targeting-positioning theory. The research questionnaire disseminated via email to consumers of CDCmodels and other clothing onlineshops.
\end{abstract}

After data proved to be valid and reliable, the rank data between CDCmodels and other clothing onlineshop processed using the Corresspondence Analysis method. The measurement of customer satisfaction on CDCmodels used hypothesis testing on average of two independent populations, using data about consumer's importance level and CDCmodels performance level. Those data also processed using Importance-Performance Analysis (IPA) method. The consumer's profile used to determine targeting and positioning that suitable for CDCmodels, also complements the CDCmodels improvement proposal. 
The priority of the marketing strategy that CDCmodels should undertake based on the combined results of Corresspondence Analysis, hypothesis testing on average of two independent populations and Importance-Performance Analysis. This study also proposed a website design for CDCmodels.

Keywords: marketing mix, e-commerce and e-business, corresspondence analysis, importanceperformance analysis, hypothesis testing

\section{Pendahuluan}

Transaksi bisnis secara online semakin disukai, baik oleh penjual maupun pembeli. Toko online atau seringkali disebut onlineshop, memungkinkan transaksi antara penjual dan pembeli secara tidak langsung, sehingga lebih fleksibel dari sisi waktu dan tempat. Berbagai produk ditawarkan melalui onlineshop ini, umumnya produk-produk yang digunakan oleh masyarakat sehari-hari, misalnya makanan, pakaian, peralatan dapur, peralatan elektronik, dan lainnya. Fasihnya masyarakat menggunakan media sosial juga turut meramaikan onlineshop ini, karena media sosial tersebut menjadi media promosi yang paling mudah dan mudah untuk digunakan, misalnya promosi melalui BBM, Kaskus, Instagram, dan lainnya.

CDCmodels merupakan salah satu onlineshop yang berdiri pada bulan Desember 2012. Yang awalnya CDCmodels hanya menjual produk sweater saja melalui BBM, seiring berjalannya waktu CDCmodels mulai menambahkan variasi jenis pakaian lainnya dan mempromosikan produknya melaui Instagram. Selama tahun 2013 CDCmodels mengalami peningkatan penjualan, namun ketatnya persaingan menyebabkan penurunan penjualan mulai Februari 2014. Hal ini mengakibatkan CDCmodels tidak lagi mampu mencapai target penjualannya.

CDCmodels membutuhkan strategi pemasaran yang tepat agar mampu memenangkan persaingan dengan onlineshop pakaian lainnya, berdasarkan targeting dan positioning yang tepat, faktor yang dipentingkan oleh konsumen onlineshop, tingkat kepuasan konsumen CDCmodels dan posisi CDCmodels dibandingkan pesaingnya. Selain itu, CDCmodels juga perlu membuat website yang baik dan mudah digunakan oleh konsumen agar konsumen mendapatkan informasi yang lengkap mengenai produk yang ditawarkan dan puas terhadap proses pemilihan hingga pembelian yang dilakukan.

\section{Tinjauan Pustaka}

Studi Pustaka ini berisi teori-teori yang digunakan dalam penelitian ini, sehingga teori-teori tersebut dapat dijadikan sebagai dasar kerangka berpikir dan landasan dalam pengolahan data serta penganalisaan data dari penelitian yang telah dilakukan.

\subsection{Bauran Pemasaran (Kotler, 1997)}

Bauran pemasaran adalah seperangkat alat pemasaran yang digunakan oleh perusahaan untuk mengejar tujuan pemasarannya pada pasar sasaran. Umumnya pada penelitian pemasaran produk, bauran pemasaran lebih dikenal dengan 4P (Product, Price, Place, dan Promotion).

- Product (Produk) adalah tawaran nyata perusahaan untuk pasar, yang mencakup kualitas, desain, fitur, merek, dan kemasan produk. Produk adalah sesuatu yang langsung dapat dirasakan atau dinikmati oleh konsumen, sehingga pengendalian terhadap suatu produk sangat penting dilakukan secara berkelanjutan."

- Price (Harga) adalah sejumlah uang yang harus dikeluarkan konsumen untuk memperoleh produk yang ditawarkan. Beberapa konsumen tidak keberatan untuk mengeluarkan uang lebih jika kualitas barang atau jasa yang mereka dapatkan dirasakan sebanding. Hal ini bisa disebabkan persepsi konsumen yang menilai kualitas suatu barang atau jasa dari sudut 
pandang nilai harganya sehingga harga sering menjadi alat untuk menjalin hubungan dengan konsumen dan digunakan sebagai alat untuk bersaing dalam merebut pangsa pasar.

- Place (Tempat/lokasi) adalah tempat di mana suatu produk atau jasa diproduksi, ditawarkan, dan dapat ditemukan oleh konsumen. Pemilihan lokasi perusahaan sering menjadi keputusan yang sangat penting karena biasanya konsumen berbelanja di tempat yang terdekat dari tempat tinggal mereka. Lokasi dapat digunakan untuk mengembangkan keunggulan bersaing perusahaan, sehingga pemilihan lokasi yang tepat adalah lokasi yang dapat menjangkau konsumen yang menjadi pasar sasarannya.

- Promotion (Promosi) merupakan aktivitas yang dilakukan sebagai bentuk usaha dengan tujuan mengomunikasikan produk atau jasa dalam menyebarkan informasi, mempengaruhi, dan mengetahui keberadaan produk atau jasa dengan tujuan agar konsumen bersedia menerima, membeli, dan loyal pada produk atau jasa yang ditawarkan perusahaan tersebut.

\subsection{E-commerce and E-business (Gary, 2012)}

Electronic Commerce adalah penjualan atau pembelian barang dan jasa, antara perusahaan, rumah tangga, individu, pemerintah dan masyarakat organisasi swasta lainnya, yang dilakukan melalui komputer pada media jaringan. Barang-barang dan jasa dipesan melalui jaringan tersebut, tetapi pembayaran dan pengiriman barang atau jasa dapat dilakukan diakhir atau offline. Pengertian Electronic Business sendiri adalah proses dimana sebuah organisasi atau perusahaan bisnis melakukan proses tersebut pada saluran jaringan pada perusahaan media elektronik. E-commerce berkaitan dengan transaksi di mana pemesanan dilakukan secara elektronik, pembayaran dan pengiriman dapat dilakukan secara offline maupun online.

Untuk E-commerse, bauran pemasaran 4P (Product, Price, Promotion dan Place), meliputi:

1. Produk (Product), terdiri dari keragaman produk, kualitas, desain, ciri, merk, kemasan, ukuran dan lain-lain.

2. Harga (Price), terdiri dari daftar harga, potongan harga, periode pembayaran, persyaratan kredit.

3. Promosi (Promotion), terdiri dari promosi penjualan, periklanan, tenaga penjualan, kehumasan, dan pemasaran langsung.

4. Tempat (Place), terdiri dari saluran pemasaran, cakupan pasar, pengelompokan, persediaan dan transportasi.

Adapun segmentasi untuk melihat perilaku pelanggan yaitu :

1. Konsumen akan mencari informasi terlebih dahulu tentang produk sebelum memutuskan akan membeli produk tersebut atau tidak, hal ini termasuk kategori konsumen Browser.

2. Konsumen akan langsung membeli produk yang di inginkan, hal ini termasuk kategori konsumen Buyers.

3. Konsumen pasti akan membeli produk namun mencari informasinya terlebih dahulu, hal ini termasuk kategori Shoppers

\subsection{Corresspondence Analysis (Hair, 2006)}

Correspondence Analysis adalah prosedur yang memungkinkan peneliti untuk memperkirakan gambaran relatif yang diterima dari sekumpulan objek-objek, dengan cara memposisikan objekobjek yang diteliti (misalnya berupa perusahaan-perusahaan, produk-produk, ide-ide, atau hal-hal lain) pada dimensi ruang.

Metode ini termasuk dalam metode compositional (attribut-based approach), dimana responden menyediakan data detail evaluasi tiap atribut untuk tiap objek, sehingga memungkinkan penggambaran atribut dan objek secara bersama-sama, lebih memudahkan peneliti untuk memahami kompetisi pasar. 
Data yang digunakan dalam Corresspondence Analysis adalah :

- Similarity-based (kemiripan)

Lebih tepat bila digunakan untuk memahami atribut/dimensi yang menggambarkan objek.

Fokus pada karakteristik dasar tiap objek dan komposisi relatifnya pada objek lain.

- Data preferensi

Lebih tepat digunakan bila peneliti ingin melihat letak objek pada perceptual map, dimana besarnya jarak menunjukkan besarnya perbedaan preferensi.

\subsection{Pengujian Hipotesis Rata-rata (Anderson, 2008)}

Uji hipotesis merupakan prosedur untuk pengambilan keputusan secara statistika, untuk memutuskan apakah menerima atau menolak hipotesis mengenai parameter yang telah dirumuskan. Salah satu bentuk pengujian hipotesis adalah pengujian hipotesis rata-rata dari 2 populasi independen.

$$
\begin{array}{ll}
\mathrm{H}_{\mathrm{o}} & : \mu_{1}=\mu_{2} \\
\mathrm{H}_{1} & : \mu_{1} \neq \mu_{2}
\end{array} \quad \text { atau } \quad \mu_{1}>\mu_{2} \quad \text { atau } \quad \mu_{1}<\mu_{2}
$$

Rumus yang digunakan :

$$
\mathrm{Z}=\frac{\left(\overline{\mathrm{x}}_{1}-\overline{\mathrm{x}}_{2}\right)-\mu_{\mathrm{d}}}{\sqrt{\frac{\mathrm{s}_{1}^{2}}{\mathrm{n}_{1}}+\frac{\mathrm{s}_{2}^{2}}{\mathrm{n}_{2}}}}
$$

Dimana :

$\mu$ : rata-rata populasi

$\mathrm{x}$ : rata-rata sampel

$\mathrm{s}:$ standard deviasi sampel

$\mathrm{n}$ : ukuran sampel

\subsection{Importance Performance Analysis (Supranto, 2001)}

Metode Importance Performance Analysis bertujuan untuk mengukur hubungan antara persepsi konsumen dan prioritas peningkatan kualitas produk/jasa. Analisis perbandingan performance (yang menunjukan kinerja suatu perusahaan atau produk) dengan importance (yang menunjukan harapan responden yang terkait dengan variabel yang diteliti) digambarkan dalam diagram kartesius, membentuk suatu bangun yang dibagi menjadi empat bagian yang dibatasi oleh dua buah garis yang berpotongan tegak lurus pada titik $(\mathrm{x}, \mathrm{y})$.

Sumbu x menunjukkan rata-rata dari rata-rata performansi dari produk atau perusahaan terhadap suatu variabel dan sumbu y menunjukkan rata-rata dari tingkat kepentingan suatu variabel. Tiap kuadran menggambarkan terjadinya suatu kondisi yang berbeda dengan kuadran lainnya. 


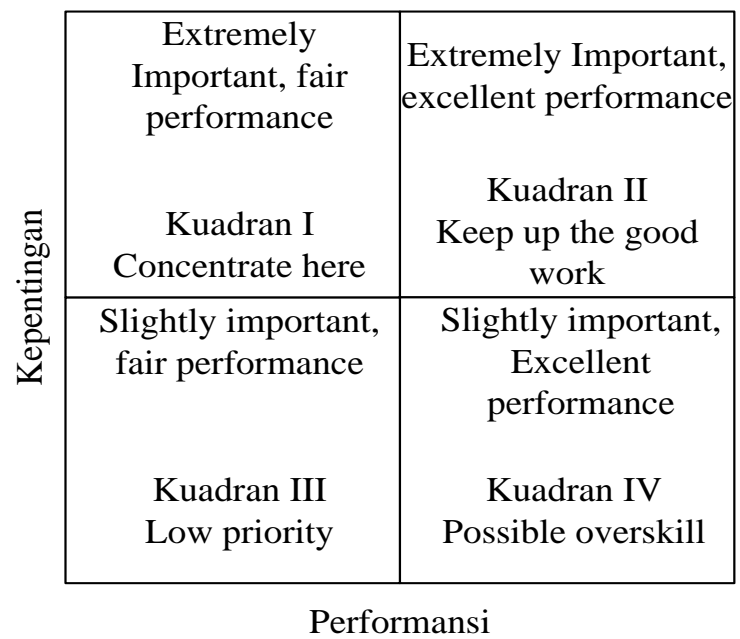

Gambar 1. Matrix Importance Performance Analysis

Keterangan:

\section{I : Prioritas Utama}

Faktor-faktor yang terletak pada kuadran ini dianggap sebagai yang penting oleh konsumen namun kondisi pada saat ini belum memuaskan sehingga pihak pengelola berkewajiban mengalokasikan sumber daya yang memadai untuk meningkatkan kinerja berbagai faktor tersebut

\section{II : Pertahankan Prestasi}

Faktor-faktor yang terletak pada kuadran ini dianggap penting sebagai faktor penunjang bagi kepuasan konsumen sehingga pihak pengelola berkewajiban memastikan bahwa kinerja dari usaha yang dikelola dapat terus dipertahankan

\section{III : Prioritas Rendah}

Faktor-faktor yang terletak pada kuadran ini mempunyai tingkat kepuasan yang rendah dan sekaligus tidak dianggap terlalu penting bagi konsumen, sehingga pihak pengelola tidak perlu memprioritaskan pada faktor-faktor tersebut.

\section{IV : Berlebihan}

Faktor-faktor yang terletak pada kuadran ini dianggap tidak terlalu penting sehingga pihak pengelola perlu mengalokasikan sumber daya untuk faktor-faktor tersebut kepada faktor-faktor

\section{Pembahasan}

\subsection{Penentuan Variabel Penelitian}

Variabel penelitian untuk segmentasi, targeting dan positioning terdiri dari :

- Demografis:

- Jenis Kelamin.

- Usia.

- Psikografis:

- Media online yang sering digunakan.

- Alasan membeli pakaian.

- Pertimbangan utama dalam membeli pakaian.

- Frekwensi pembelian pakaian.

- Kisaran harga pakaian yang dibeli.

- Pakaian yang sering dibeli.

- Kategori buyer.

- Sumber informasi mengenai CDCmodels.

- Minat untuk membeli kembali di CDCmodels.

- Minat untuk merekomendasikan CDCmodels pada orang lain. 
Variabel penelitian untuk mengukur tingkat kepentingan konsumen dan mengukur performansi CDCmodels, disusun berdasarkan bauran pemasaran 4P, yang digunakan untuk E-Business andCommerce, yaitu :

- Product, terdiri dari keragaman produk, kualitas, desain, ciri, merek, ukuran, persepsi pelanggan.

1. Variasi jenis produk yang ditawarkan (dress, rok, sweater, baju atasan).

2. Variasi model yang ditawarkan.

3. Variasi warna yang ditawarkan.

4. Kelengkapan ukuran.

5. Kerapihan jahitan.

6. Kualitas bahan.

7. Kerapihan plastik pengemasan untuk mengirim produk.

8. Detail foto produk yang jelas (tampak depan, belakang, dll).

- Price, terdiri dari daftar harga, harga produk bersaing, potongan harga, periode pembayaran.

9. Harga yang ditawarkan sesuai dengan kualitas produk.

10. Harga yang bersaing dengan onlineshop lain.

11. Kejelasan daftar harga yang ditawarkan.

12. Kemenarikan program diskon yang diberikan kepada konsumen setiap hari raya (hari raya Natal, hari raya Idul Fitri, hari raya Tahun Baru).

13. Kemenarikan program diskon yang diberikan setiap bulan.

14. Kemudahan pembayaran.

- Promotion, terdiri dari promosi penjualan, periklanan, tenaga penjualan, kehumasan dan pemasaran langsung.

15. Tampilan iklan yang menarik di sosial media (Facebook, Instagram, Website, Twitter, Email, dll).

16. Keramahan pegawai dalam melayani konsumen saat membalas pesan konsumen.

17. Kecepatan respon pegawai kepada konsumen.

18. Pengetahuan pegawai tentang produk.

19. Pegawai yang meyakinkan konsumen untuk berbelanja di CDCmodels.

20. Ketepatan pengiriman produk kepada konsumen.

21. Info tentang produk terbaru yang dikeluarkan.

22. Kecepatan penukaran barang cacat.

23. Kecepatan pengembalian uang jika barang ternyata habis.

24. Jaminan atau masa garansi terhadap produk.

25. Kejelasan akan keberadaan produk yang telah dibeli konsumen (mulai dari produk sedang dikemas, sudah diantar ke jasa pengirman, sedang di perjalanan, hingga produk sudah diterima).

- Place, terdiri dari saluran pemasaran, cakupan pasar, pengelompokan, persediaan, transportasi.

26. Kemudahan mencari info tentang toko online.

27. Kejelasan info tentang sisa baju yang tersedia.

28. Kejelasan info tentang barang yang sedang kosong atau habis.

29. Keluasan jangkauan penjualan toko online (nasional, internasional).

30. Tampilan media sosial yang menarik

\subsection{Langkah-langkah Pembuatan Website}

Pembuatan website dilakukan sesuai tujuan pembuatan website dan objective e-biz, yaitu :

1. Mempromosikan bisnis melalui Web

2. Memperbaiki sistem customer service

3. Konsumen prospektif dapat mencoba untuk membeli produk secara online 
Pencarian ide untuk variabel dalam Web :

1. Content

2. Aspek Desain

3. Fungsional

\subsection{Pengumpulan Data}

Data yang digunakan dalam penelitian ini dikumpulkan melalui kuesioner penelitian, yang terdiri dari 3 bagian yaitu:

- Bagian pertama berisi profil responden dengan variabel penelitian untuk segmenting, targeting dan positioning.

- Bagian kedua berisi pengukuran harapan atau tingkat kepentingan konsumen akan onlineshop pakaian (skala Likert Sangat Tidak Penting hingga Sangat Penting / 1 hingga 4) dan pengukuran performansi CDCmodels menurut konsumen (skala Likert Sangat Tidak Baik hingga Sangat Baik / 1 hingga 4).

- Bagian ketiga berisi penilaian perbandingan CDCmodels dan onlineshop pakaian lainnya. Yang dijadikan pesaing adalah seluruh onlineshop yang menjual pakaian sejenis dengan CDCmodels. Onlineshop yang dinilai lebih baik diberikan peringkat 1 , dan yang dinilai lebih buruk diberikan peringkat 2 .

Jumlah sampel minimum menggunakan rumus Paul Ledy yaitu :

$$
\mathrm{N}=\left(\frac{\mathrm{z}}{\mathrm{e}}\right)^{2}(\mathrm{p})(1-\mathrm{p})
$$

dimana :

$\mathrm{N}$ = ukuran sampel minimum

$\mathrm{Z}$ = nilai dari tabel distribusi Normal

e = sampling error atau tingkat ketelitian yang dipergunakan

$\mathrm{p}=$ proporsi populasi yang akan diteliti.

Jika proporsi populasi tidak diketahui, maka ditetapkan $\mathrm{p}=0.5$.

Sehingga :

$$
\begin{aligned}
N & =\left(\frac{\mathrm{z}_{0,05 / 2}}{0,1}\right)^{2}(0,5)(1-0,5) \\
& =\left(\frac{1,96}{0,1}\right)^{2}(0,5)(1-0,5)=96.04 \approx 97 \text { responden }
\end{aligned}
$$

Jumlah sampel minimum 97 responden, namun kuesioner disebarkan pada 150 pelanggan CDCmodels yang juga melakukan pembelian pakaian pada onlineshop lain (metode sampling purposive). Kuesioner disebarkan melalui email dan untuk meningkatkan minat pelanggan mengisi kuesioner maka pelanggan yang mengisi kuesioner diberikan potongan harga saat pembelian pakaian di CDCmodels. Pada proses pengolahan data, hanya 120 kuesioner yang terisi dengan benar yang akan diolah.

\subsection{Pembahasan}

\subsubsection{Hasil Pengolahan Kuesioner Penelitian}

Setelah terbukti bahwa data hasil pengumpulan kuesioner penelitian valid (nilai $\mathrm{r}$ variabel tingkat kepentingan antara 0.199 hingga $0.445>$ nilai $\mathrm{r}$ minimum yaitu 0.1798 ) dan reliabel (nilai $\alpha=$ $0.781>0.7)$ maka data dapat diproses lanjut. Sesuai tujuan penelitian, dilakukan pengolahan data sebagai berikut:

1. Untuk mengetahui kelebihan dan kelemahan CDCmodels dibandingkan onlineshop pakaian lainnya, pengolahan data peringkat diolah menggunakan metode Correspondence Analysis. 
2. Pengukuran tingkat kepuasan konsumen terhadap CDCmodels menggunakan pengujian hipotesis rata-rata dua populasi independen, dengan data tingkat kepentingan konsumen akan onlineshop pakaian dan tingkat performansi CDCmodels.

3. Perbandingan antara performansi CDCmodels dan tingkat kepentingan konsumen akan onlineshop pakaian menggunakan diagram kartesius Importance-Performance Analysis (IPA).

4. Segmentasi, targeting dan positioning yang tepat bagi CDCmodels didapatkan dengan menghitung persentase data profil responden.

5. Prioritas strategi pemasaran yang harus dilakukan oleh CDCmodels berdasarkan hasil pengolahan kuesioner penelitian yang telah dilakukan dan segmentasi-targetingpositioning yang diusulkan.

6. Merancang website bagi CDCmodels.

\section{A. Hasil Pengolahan Kuesioner Penelitian: Correspondence Analysis}

Kelebihan dan kelemahan CDCmodels didapatkan dari grafik Correspondence Analysis. CDCmodels dikatakan unggul apabila jarak antara variabel dan CDCmodels lebih dekat dibandingkan jarak antara variabel tersebut dan Onlineshop lain.

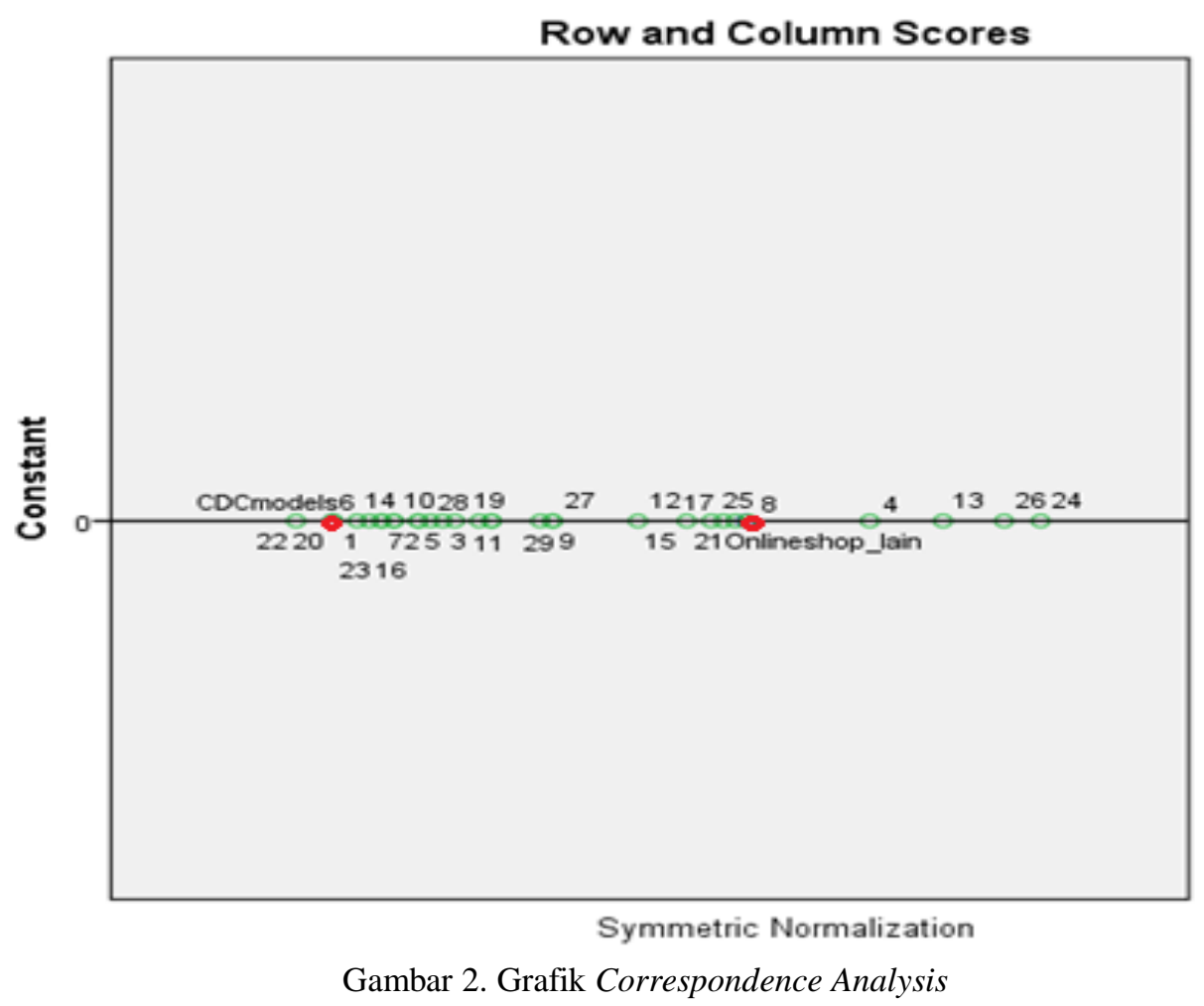

Berdasarkan jarak pada grafik diatas, berikut adalah keunggulan dan kelemahan CDCmodels dibandingkan onlineshop lain: 
Tabel 1. Keunggulan dan Kelemahan CDCmodels dibandingkan Onlineshop lain

\begin{tabular}{|c|c|c|}
\hline \multirow{18}{*}{ Keunggulan } & $\begin{array}{l}\text { No. } \\
\text { Var }\end{array}$ & Variabel \\
\hline & 1 & $\begin{array}{l}\text { Variasi jenis produk yang ditawarkan (dress, rok, sweater, baju } \\
\text { atasan). }\end{array}$ \\
\hline & 2 & Variasi model yang ditawarkan. \\
\hline & 3 & Variasi warna yang ditawarkan. \\
\hline & 5 & Kerapihan jahitan. \\
\hline & 6 & Kualitas bahan. \\
\hline & 7 & Kerapihan plastik pengemasan untuk mengirim produk. \\
\hline & 10 & Harga yang bersaing dengan onlineshop lain. \\
\hline & 11 & Kejelasan daftar harga yang ditawarkan. \\
\hline & 14 & Kemudahan pembayaran. \\
\hline & 16 & $\begin{array}{l}\text { Keramahan pegawai dalam melayani konsumen saat membalas pesan } \\
\text { konsumen. }\end{array}$ \\
\hline & 18 & Pengetahuan pegawai tentang produk. \\
\hline & 19 & $\begin{array}{l}\text { Pegawai yang meyakinkan konsumen untuk berbelanja di } \\
\text { CDCmodels. }\end{array}$ \\
\hline & 20 & Ketepatan pengiriman produk kepada konsumen. \\
\hline & 22 & Kecepatan penukaran barang cacat. \\
\hline & 23 & Kecepatan pengembalian uang jika barang ternyata habis. \\
\hline & 28 & Kejelasan info tentang barang yang sedang kosong atau habis. \\
\hline & 30 & Tampilan media sosial yang menarik \\
\hline \multirow{14}{*}{ Kelemahan } & $\begin{array}{l}\text { No. } \\
\text { Var }\end{array}$ & Variabel \\
\hline & 4 & Kelengkapan ukuran. \\
\hline & 8 & Detail foto produk yang jelas (tampak depan, belakang, dll). \\
\hline & 9 & Harga yang ditawarkan sesuai dengan kualitas produk. \\
\hline & 12 & $\begin{array}{l}\text { Kemenarikan program diskon yang diberikan kepada konsumen } \\
\text { setiap hari raya (hari raya Natal, hari raya Idul Fitri, hari raya Tahun } \\
\text { Baru). }\end{array}$ \\
\hline & 13 & Kemenarikan program diskon yang diberikan setiap bulan. \\
\hline & 15 & $\begin{array}{l}\text { Tampilan iklan yang menarik di sosial media (Facebook, Instagram, } \\
\text { Website, Twitter, Email, dll). }\end{array}$ \\
\hline & 17 & Kecepatan respon pegawai kepada konsumen. \\
\hline & 21 & Info tentang produk terbaru yang dikeluarkan. \\
\hline & 24 & Jaminan atau masa garansi terhadap produk. \\
\hline & 25 & $\begin{array}{l}\text { Kejelasan akan keberadaan produk yang telah dibeli konsumen } \\
\text { (mulai dari produk sedang dikemas, sudah diantar ke jasa pengirman, } \\
\text { sedang di perjalanan, hingga produk sudah diterima). }\end{array}$ \\
\hline & 26 & Kemudahan mencari info tentang toko online. \\
\hline & 27 & Kejelasan info tentang sisa baju yang tersedia. \\
\hline & 29 & Keluasan jangkauan penjualan toko online (nasional, internasional). \\
\hline
\end{tabular}

\section{B. Hasil Pengolahan Kuesioner Penelitian: Importance Performance Analysis}

Importance Performance Analysis digunakan untuk menganalisis perbandingan antara kinerja CDCmodels dengan tingkat kepentingan konsumen akan onlineshop pakaian. Dari matriks IPA yang terbentuk, dapat terlihat prioritas perbaikan yang harus dilakukan pada variabel yang diteliti.

Nilai batas kuadran pada matriks IPA didapatkan dari nilai rata-rata kinerja dan kepentingan dari 30 variabel yang diteliti, yaitu nilai garis tengah untuk sumbu X (Kepentingan): 3.31 dan nilai garis tengah untuk sumbu Y (Kinerja): 2.91. 


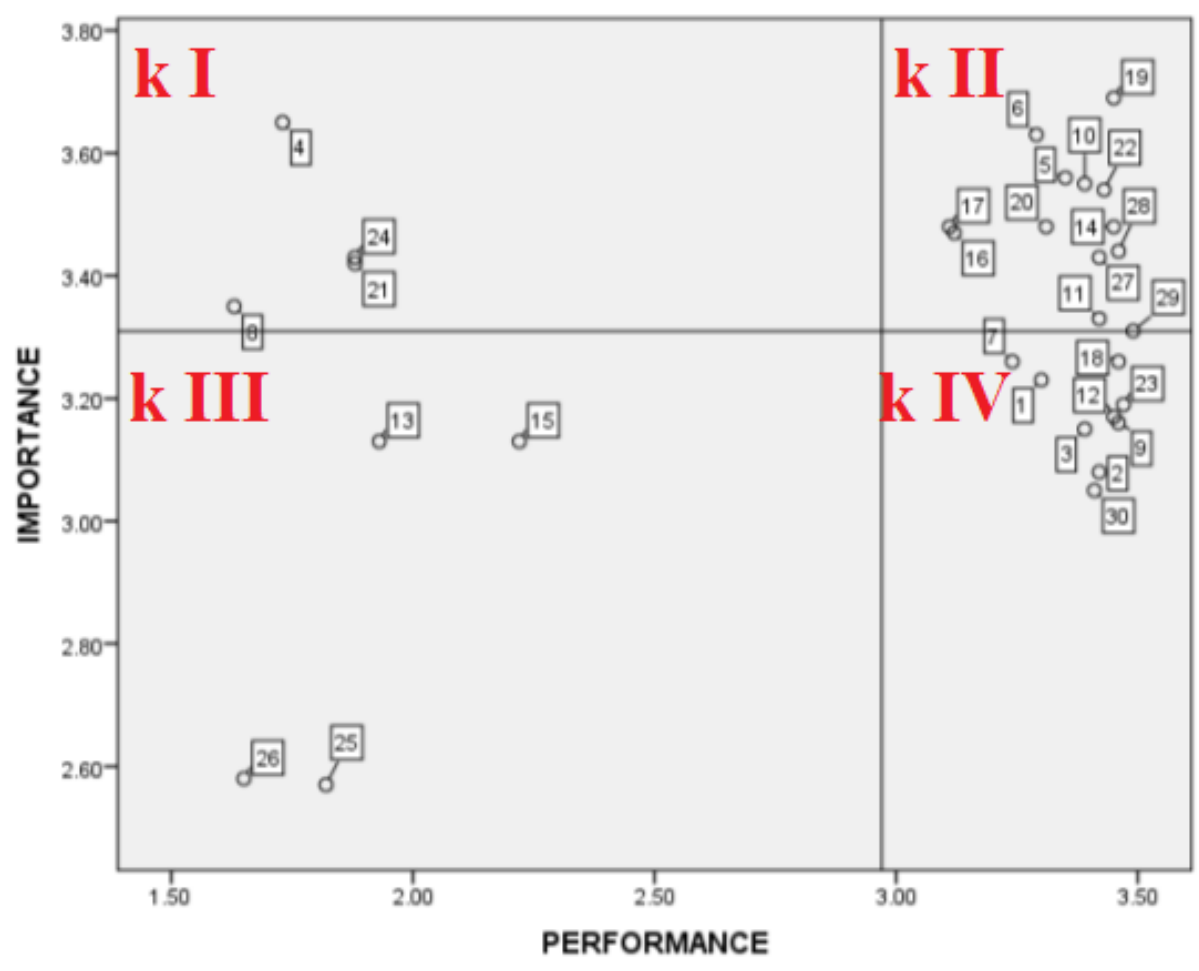

Gambar 3. Matriks Importance-Performance Analysis

Variabel-variabel yang berada pada kuadran I menunjukkan bahwa kinerja Onlineshop CDCmodels berada dibawah rata-rata, namun tingkat kepentingan konsumen akan variabel tersebut diatas ratarata sehingga CDCmodels harus meningkatkan kinerjanya agar dapat memenuhi tingkat kepentingan konsumen yang tinggi akan variabel tersebut.

Kuadran II berisi variabel dengan kinerja CDCmodels dan tingkat kepentingan konsumen yang diatas rata-rata, artinya CDCmodels harus mempertahankan kinerjanya.

CDCmodels memiliki kinerja dan kepentingan yang dibawah rata-rata untuk variabel-variabel yang berada pada kuadran III, namun perlu diperhatikan nilai tingkat kepentingan untuk setiap variabel di kuadran III ini karena ada variabel yang memiliki nilai kepentingan diatas 3.00 yang artinya konsumen mementingkan variabel tersebut walaupun nilai tingkat kepentingannya di bawah ratarata.

Variabel yang berada di kuadran IV adalah variabel yang memiliki tingkat kinerja di atas rata-rata namun tingkat kepentingannya di bawah rata-rata. Sama seperti variabel-variabel pada kuadran III, perlu diperhatikan nilai tingkat kepentingan untuk setiap variabel di kuadran IV ini karena hampir seluruhnya berada diatas 3.00 . 


\section{Hasil Pengolahan Kuesioner Penelitian: Pengujian Hipotesis Rata-rata 2 Populasi Independen}

Pengujian hipotesis untuk rata-rata 2 populasi independen digunakan untuk mengetahui tingkat kepuasan konsumen pada CDCmodels. Data yang digunakan adalah tingkat kepentingan konsumen saat berbelanja di onlineshop pakaian dan dan tingkat performansi CDCmodels, dimana :

$\mu_{1}$ : rata-rata tingkat kinerja CDCmodels

$\mu_{2}$ : rata-rata tingkat kepentingan konsumen sat berbelanja di onlineshop pakaian

$\mathrm{H}_{\mathrm{o}} \quad: \mu_{1}-\mu_{2}=0$ (Konsumen puas)

$\mathrm{H}_{1} \quad: \mu_{1}-\mu_{2}<0$ (Konsumen tidak puas)

Rumus yang digunakan :

$$
\mathrm{Z}=\frac{\left(\overline{\mathrm{x}}_{1}-\overline{\mathrm{x}}_{2}\right)-\mu_{\mathrm{d}}}{\sqrt{\frac{\mathrm{s}_{1}^{2}}{\mathrm{n}_{1}}+\frac{\mathrm{s}_{2}^{2}}{\mathrm{n}_{2}}}}
$$

Keputusan : Konsumen puas bila nilai $\mathrm{Z}$ hitung > wilayah kritis.

Wilayah kritis : diambil dari tabel distribusi normal dengan $\alpha=0,05$ yaitu $-1,645$, contoh pada variabel 1 didapatkan nilai $\mathrm{Z}$ hitung $=1.014$ sehingga disimpulkan bahwa konsumen puas pada variabel 1.

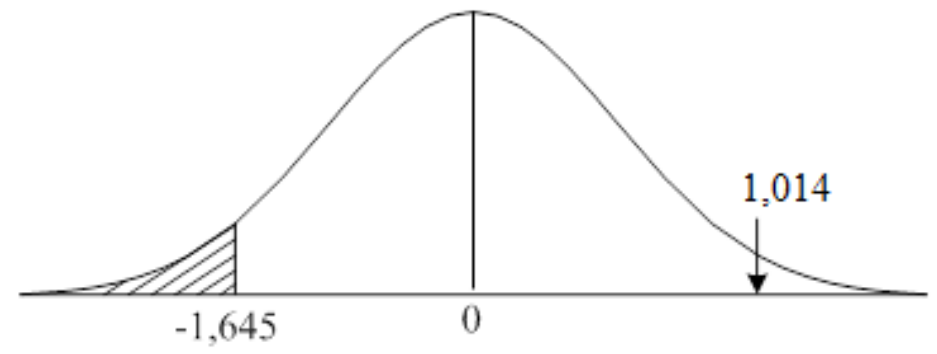

Gambar 4. Wilayah Kritis Pengujian Hipotesis Rata-rata

Berikut adalah hasil pengujian hipotesis rata-rata untuk masing-masing variabel :

Tabel 4. Hasil Pengujian Hipotesis Rata-rata Untuk Tiap Variabel

\begin{tabular}{|c|l|c|c|}
\hline \multirow{2}{*}{ No } & \multicolumn{1}{|c|}{ Variabel } & \multicolumn{2}{c|}{ Hasil Pengujian Hipotesis } \\
\cline { 3 - 4 } & & $\begin{array}{c}\text { Z } \\
\text { hitung }\end{array}$ & Kesimpulan \\
\hline 1 & $\begin{array}{l}\text { Variasi jenis produk yang ditawarkan (dress, rok, } \\
\text { sweater, baju atasan). }\end{array}$ & 1.014 & Konsumen Puas \\
\hline 2 & Variasi model yang ditawarkan. & 3.725 & Konsumen Puas \\
\hline 3 & Variasi warna yang ditawarkan. & 2.755 & Konsumen Puas \\
\hline 4 & Kelengkapan ukuran. & -28.930 & Konsumen Tidak Puas \\
\hline 5 & Kerapihan jahitan. & -3.301 & Konsumen Tidak Puas \\
\hline 6 & Kualitas bahan. & -5.626 & Konsumen Tidak Puas \\
\hline 7 & $\begin{array}{l}\text { Kerapihan plastik pengemasan untuk mengirim } \\
\text { produk. }\end{array}$ & -0.230 & Konsumen Puas \\
\hline 8 & $\begin{array}{l}\text { Detail foto produk yang jelas (tampak depan, } \\
\text { belakang, dll). }\end{array}$ & -23.056 & Konsumen Tidak Puas \\
\hline
\end{tabular}


Tabel 4. Hasil Pengujian Hipotesis Rata-rata Untuk Tiap Variabel (Lanjutan)

\begin{tabular}{|c|c|c|c|}
\hline \multirow[b]{2}{*}{ No } & \multirow[b]{2}{*}{ Variabel } & \multicolumn{2}{|c|}{ Hasil Pengujian Hipotesis } \\
\hline & & $\begin{array}{c}\mathrm{Z} \\
\text { hitung }\end{array}$ & Kesimpulan \\
\hline 9 & $\begin{array}{l}\text { Harga yang ditawarkan sesuai dengan kualitas } \\
\text { produk. }\end{array}$ & 4.174 & Konsumen Puas \\
\hline 10 & Harga yang bersaing dengan onlineshop lain. & -2.478 & Konsumen Tidak Puas \\
\hline 11 & Kejelasan daftar harga yang ditawarkan. & 1.159 & Konsumen Puas \\
\hline 12 & $\begin{array}{l}\text { Kemenarikan program diskon yang diberikan } \\
\text { kepada konsumen setiap hari raya (hari raya Natal, } \\
\text { hari raya Idul Fitri, hari raya Tahun Baru). }\end{array}$ & 3.414 & Konsumen Puas \\
\hline 13 & $\begin{array}{l}\text { Kemenarikan program diskon yang diberikan setiap } \\
\text { bulan. }\end{array}$ & -14.687 & Konsumen Tidak Puas \\
\hline 14 & Kemudahan pembayaran. & -0.516 & Konsumen Puas \\
\hline 15 & $\begin{array}{l}\text { Tampilan iklan yang menarik di sosial media } \\
\text { (Facebook, Instagram, Website, Twitter, Email, } \\
\text { dll). }\end{array}$ & -12.714 & Konsumen Tidak Puas \\
\hline 16 & $\begin{array}{l}\text { Keramahan pegawai dalam melayani konsumen } \\
\text { saat membalas pesan konsumen. }\end{array}$ & -4.854 & Konsumen Tidak Puas \\
\hline 17 & Kecepatan respon pegawai kepada konsumen. & -5.413 & Konsumen Tidak Puas \\
\hline 18 & Pengetahuan pegawai tentang produk. & 2.764 & Konsumen Puas \\
\hline 19 & $\begin{array}{l}\text { Pegawai yang meyakinkan konsumen untuk } \\
\text { berbelanja di CDCmodels. }\end{array}$ & -3.884 & Konsumen Tidak Puas \\
\hline 20 & Ketepatan pengiriman produk kepada konsumen. & -2.507 & Konsumen Tidak Puas \\
\hline 21 & Info tentang produk terbaru yang dikeluarkan. & -21.664 & Konsumen Tidak Puas \\
\hline 22 & Kecepatan penukaran barang cacat. & -1.682 & Konsumen Tidak Puas \\
\hline 23 & $\begin{array}{l}\text { Kecepatan pengembalian uang jika barang ternyata } \\
\text { habis. }\end{array}$ & 3.619 & Konsumen Puas \\
\hline 24 & Jaminan atau masa garansi terhadap produk. & -21.461 & Konsumen Tidak Puas \\
\hline 25 & $\begin{array}{l}\text { Kejelasan akan keberadaan produk yang telah } \\
\text { dibeli konsumen (mulai dari produk sedang } \\
\text { dikemas, sudah diantar ke jasa pengirman, sedang } \\
\text { di perjalanan, hingga produk sudah diterima). }\end{array}$ & -6.926 & Konsumen Tidak Puas \\
\hline 26 & Kemudahan mencari info tentang toko online. & -8.039 & Konsumen Tidak Puas \\
\hline 27 & Kejelasan info tentang sisa baju yang tersedia. & -0.114 & Konsumen Puas \\
\hline 28 & $\begin{array}{l}\text { Kejelasan info tentang barang yang sedang kosong } \\
\text { atau habis. }\end{array}$ & 0.226 & Konsumen Puas \\
\hline 29 & $\begin{array}{l}\text { Keluasan jangkauan penjualan toko online } \\
\text { (nasional, internasional). }\end{array}$ & 2.426 & Konsumen Puas \\
\hline 30 & Tampilan media online yang menarik & 4.599 & Konsumen Puas \\
\hline
\end{tabular}

Berdasarkan hasil pengujian hipotesis rata-rata diatas didapatkan bahwa dari 30 variabel, hanya separuhnya yang memberikan kepuasan bagi konsumen. 


\section{Hasil Pengolahan Kuesioner Penelitian: Segmentasi, Targeting dan Positioning}

Profil konsumen yang didapatkan dari kuesioner penelitian, dihitung nilai persentasenya, untuk menentukan targeting dan positioning yang tepat bagi CDCmodels.

Tabel 5. Profil Responden

\begin{tabular}{|c|c|c|c|c|}
\hline No & Pertanyaan & Jawaban & Jumlah & $\%$ \\
\hline \multirow{2}{*}{1} & \multirow{2}{*}{ Jenis Kelamin } & Pria & 23 & 19 \\
\hline & & Wanita & 97 & 81 \\
\hline \multirow{4}{*}{2} & \multirow{4}{*}{ Usia } & $<18$ tahun & 28 & 23 \\
\hline & & 19 tahun -24 tahun & 50 & 42 \\
\hline & & 25 tahun -47 tahun & 36 & 30 \\
\hline & & $>47$ tahun & 6 & 5 \\
\hline \multirow{4}{*}{3} & \multirow{4}{*}{$\begin{array}{c}\text { Sumber Mengetahui } \\
\text { CDCmodels }\end{array}$} & Keluarga/Teman & 28 & 23 \\
\hline & & Media Sosial & 60 & 50 \\
\hline & & Internet & 25 & 21 \\
\hline & & Lainnya (Plastik packing CDCmodels, google) & 7 & 6 \\
\hline \multirow{7}{*}{4} & \multirow{7}{*}{$\begin{array}{l}\text { Media Online yang } \\
\text { sering dikunjungi }\end{array}$} & Instagram & 43 & 36 \\
\hline & & Facebook & 17 & 14 \\
\hline & & Tokopedia & 10 & 8 \\
\hline & & Twitter & 14 & 12 \\
\hline & & Lazada & 19 & 16 \\
\hline & & blibli.com & 9 & 8 \\
\hline & & Lainnya (Website) & 8 & 7 \\
\hline \multirow{6}{*}{5} & \multirow{6}{*}{$\begin{array}{c}\text { Alasan membeli } \\
\text { pakaian }\end{array}$} & Kebutuhan & 22 & 18 \\
\hline & & Fashion & 34 & 28 \\
\hline & & Update style & 20 & 17 \\
\hline & & Koleksi & 17 & 14 \\
\hline & & Hobby & 19 & 16 \\
\hline & & Lainnya (Kebetulan, iseng-iseng, laper mata) & 8 & 7 \\
\hline \multirow{7}{*}{6} & \multirow{7}{*}{$\begin{array}{l}\text { Hal utama yang } \\
\text { menjadi } \\
\text { pertimbangan dalam } \\
\text { membeli pakaian }\end{array}$} & Model atau desain & 26 & 22 \\
\hline & & Harga & 32 & 27 \\
\hline & & Kualitas produk & 18 & 15 \\
\hline & & Trend fashion & 11 & 9 \\
\hline & & Merk & 14 & 12 \\
\hline & & Variasi warna dan corak & 16 & 13 \\
\hline & & Lainnya (Fungsinya) & 3 & 3 \\
\hline \multirow{4}{*}{7} & \multirow{4}{*}{$\begin{array}{l}\text { Jenis pakaian yang } \\
\text { sering dibeli di } \\
\text { CDCmodels }\end{array}$} & Baju atasan & 24 & 20 \\
\hline & & Jaket & 38 & 32 \\
\hline & & Sweater & 31 & 26 \\
\hline & & Dress & 27 & 23 \\
\hline
\end{tabular}


JOURNAL OF INTEGRATED SYSTEM VOL 1. NO. 1, JUNI 2018: 105-127

Tabel 5. Profil Responden (Lanjutan)

\begin{tabular}{|c|c|c|c|c|}
\hline No & Pertanyaan & Jawaban & Jumlah & $\%$ \\
\hline \multirow{6}{*}{8} & \multirow{6}{*}{$\begin{array}{l}\text { Pembelian pakaian } \\
\text { dalam } 1 \text { bulan }\end{array}$} & 1 kali & 19 & 16 \\
\hline & & 2 kali & 28 & 23 \\
\hline & & 3 kali & 19 & 16 \\
\hline & & 4 kali & 16 & 13 \\
\hline & & $>4$ kali & 17 & 14 \\
\hline & & Lainnya (Tidak pernah / 0) & 21 & 18 \\
\hline \multirow{5}{*}{9} & \multirow{5}{*}{$\begin{array}{c}\text { Kisaran harga } \\
\text { pakaian online yang } \\
\text { sering dibeli }\end{array}$} & $<\mathrm{Rp} 100.000$ & 36 & 30 \\
\hline & & Rp 100.000 - Rp 150.000 & 32 & 27 \\
\hline & & $\mathrm{Rp} 150.001-\mathrm{Rp} 200.000$ & 23 & 19 \\
\hline & & Rp $200.001-\operatorname{Rp} 300.000$ & 20 & 17 \\
\hline & & > Rp 300.000, yaitu (Zara, Adidas, Vans, Nike) & 9 & 8 \\
\hline \multirow{3}{*}{10} & \multirow{3}{*}{ Kategori } & $\begin{array}{l}\text { Mencari info terlebih dahulu tentang produk } \\
\text { sebelum memutuskan membeli atau tidak }\end{array}$ & 38 & 32 \\
\hline & & Langsung membeli produk yang diinginkan & 38 & 32 \\
\hline & & $\begin{array}{l}\text { Pasti akan membeli produk namun mencari } \\
\text { infonya terlebih dahulu }\end{array}$ & 44 & 37 \\
\hline \multirow{4}{*}{11} & \multirow{4}{*}{$\begin{array}{c}\text { Berminat untuk } \\
\text { memesan pakaian } \\
\text { kembali di } \\
\text { CDCmodels }\end{array}$} & Sangat berminat & 46 & 38.3 \\
\hline & & Berminat & 45 & 37.5 \\
\hline & & Tidak berminat & 15 & 13 \\
\hline & & $\begin{array}{c}\text { Sangat tidak berminat, karena lama dalam proses } \\
\text { pengiriman }\end{array}$ & 14 & 12 \\
\hline \multirow{4}{*}{12} & \multirow{4}{*}{$\begin{array}{l}\text { Merekomendasikan } \\
\text { CDCmodels kepada } \\
\text { orang lain }\end{array}$} & Sangat akan merekomendasikan & 46 & 38.3 \\
\hline & & Merekomendasikan & 45 & 37.5 \\
\hline & & Tidak akan merekomendasikan & 15 & 13 \\
\hline & & $\begin{array}{l}\text { Sangat tidak akan merekomendasikan, karena lama } \\
\text { dalam proses pengiriman }\end{array}$ & 14 & 12 \\
\hline
\end{tabular}

Hasil profil konsumen membantu CDCmodels menentukan target pasarnya yaitu konsumen wanita berusia 19-47 tahun, mengetahui CDCmodels dari media sosial, sering menggunakan Instagram, menyukai model pakaian dengan fashion terkini, lebih mengutamakan harga dan model/desain dalam membeli pakaian, membeli semua jenis pakaian (baju atasan, jaket, sweater, dress), membeli pakaian sebanyak 2 kali dalam 1 bulan dengan kisaran harga $<\mathrm{Rp} 150.000$, mencari informasi yang jelas tentang pakaian sebelum membeli.

Positioning statement yang diusulkan agar CDCmodels ada di benak konsumen saat berbelanja di onlinestore pakaian adalah "GUES\$ = Good, Unique, Safe":

- Good (Baik) karena berdasarkan keunggulan CDCmodels dari metode Corresspondence Analysis yaitu kerapihan jahitan, kualitas bahan, kerapihan plastik pengemasan, harga yang ditawarkan, kejelasan daftar harga, kemudahan pembayaran, keramahan pegawai dalam melayani konsumen, dan pengetahuan pegawai tentang produk.

- Unique (Unik) karena CDCmodels mempunyai keunggulan mulai dari variasi jenis produk yang ditawarkan, variasi model produk yang ditawarkan, variasi warna yang ditawarkan dan plastik pengemasan. 
- $\quad$ Safe (Aman) karena CDCmodels mempunyai keunggulan mulai dari ketepatan pengiriman produk kepada konsumen, kecepatan penukaran produk, dan kecepatan pengembalian uang jika produk ternyata habis.

\section{Penentuan Prioritas Perbaikan}

Prioritas perbaikan bagi CDCmodels dibuat berdasarkan ketiga hasil pengolahan data, yaitu:

1. Variabel yang merupakan kelemahan berdasarkan hasil Correspondence Analysis merupakan prioritas perbaikan yang lebih didahulukan.

2. Mengurutkan kuadran pada matriks Importance-Performance Analysis, yaitu prioritas lebih utama diberikan pada Kuadran I, prioritas selanjutnya diberikan pada Kuadran II, Kuadran III, dan Kuadran IV.

3. Prioritas lebih utama diberikan pada variabel yang paling tidak memuaskan konsumen, yaitu variabel yang memiliki nilai $\mathrm{Z}$ hitung terendah.

Tabel 6. Penentuan Prioritas Perbaikan

\begin{tabular}{|c|c|c|c|c|c|}
\hline $\begin{array}{l}\text { No. } \\
\text { Var }\end{array}$ & Atribut & CA & $\begin{array}{l}\text { Kuadran } \\
\text { IPA }\end{array}$ & $\begin{array}{c}\text { Z } \\
\text { Hitung }\end{array}$ & Prioritas \\
\hline 4 & Kelengkapan ukuran & \multirow{13}{*}{ Tertinggal } & \multirow{4}{*}{ I } & -28.93 & \multirow{4}{*}{1} \\
\hline 8 & $\begin{array}{l}\text { Detail foto produk yang jelas (tampak depan, } \\
\text { belakang) }\end{array}$ & & & -23.06 & \\
\hline 21 & Info tentang produk terbaru yang dikeluarkan & & & -21.66 & \\
\hline 24 & Jaminan atau masa garansi terhadap produk & & & -21.46 & \\
\hline 17 & Kecepatan respon pegawai kepada konsumen & & \multirow{3}{*}{ II } & -5.41 & \multirow{3}{*}{2} \\
\hline 27 & Kejelasan info tentang sisa baju yang tersedia & & & -0.11 & \\
\hline 29 & $\begin{array}{l}\text { Keluasan jangkauan penjualan toko online } \\
\text { (nasional, internasional) }\end{array}$ & & & 2.43 & \\
\hline 13 & $\begin{array}{l}\text { Kemenarikan program diskon yang diberikan } \\
\text { setiap bulan }\end{array}$ & & \multirow{4}{*}{ III } & -14.69 & \multirow{4}{*}{3} \\
\hline 15 & Tampilan iklan yang menarik di sosial media & & & -12.71 & \\
\hline 26 & Kemudahan mencari info tentang toko online & & & -8.04 & \\
\hline 25 & $\begin{array}{l}\text { Kejelasan akan keberadaan produk yang telah } \\
\text { dibeli konsumen }\end{array}$ & & & -6.93 & \\
\hline 9 & $\begin{array}{l}\text { Harga yang ditawarkan sesuai dengan kualitas } \\
\text { produk }\end{array}$ & & \multirow{2}{*}{ IV } & 4.17 & \multirow{2}{*}{4} \\
\hline 12 & $\begin{array}{l}\text { Kemenarikan program diskon yang diberikan } \\
\text { kepada konsumen setiap hari raya }\end{array}$ & & & 3.41 & \\
\hline 6 & Kualitas bahan & \multirow{5}{*}{ Unggul } & \multirow{5}{*}{ II } & -5.63 & \multirow{5}{*}{5} \\
\hline 16 & $\begin{array}{llll}\begin{array}{l}\text { Keramahan } \\
\text { konsumen }\end{array} & \text { pegawai } & \text { dalam } & \text { melayani } \\
\end{array}$ & & & -4.85 & \\
\hline 19 & $\begin{array}{l}\text { Pegawai yang meyakinkan konsumen untuk } \\
\text { berbelanja di CDCmodels }\end{array}$ & & & -3.88 & \\
\hline 5 & Kerapihan jahitan & & & -3.30 & \\
\hline 20 & $\begin{array}{l}\text { Ketepatan pengiriman } \\
\text { konsumen }\end{array}$ & & & -2.51 & \\
\hline
\end{tabular}


Tabel 6. Penentuan Prioritas Perbaikan (Lanjutan)

\begin{tabular}{|c|c|c|c|c|c|}
\hline $\begin{array}{l}\text { No. } \\
\text { Var }\end{array}$ & Atribut & $\mathbf{C A}$ & $\begin{array}{l}\text { Kuadran } \\
\text { IPA }\end{array}$ & $\begin{array}{c}\text { Z } \\
\text { Hitung }\end{array}$ & Prioritas \\
\hline 10 & $\begin{array}{l}\text { Harga yang bersaing dengan onlineshop yang } \\
\text { lain }\end{array}$ & \multirow{12}{*}{ Unggul } & \multirow{5}{*}{ II } & -2.48 & \multirow{5}{*}{5} \\
\hline 22 & $\begin{array}{l}\text { Kecepatan Penukaran barang jika ada yang } \\
\text { cacat }\end{array}$ & & & -1.68 & \\
\hline 14 & Kemudahan Pembayaran & & & -0.52 & \\
\hline 28 & $\begin{array}{l}\text { Kejelasan info tentang barang yang sedang } \\
\text { kosong atau habis }\end{array}$ & & & 0.23 & \\
\hline 11 & Kejelasan daftar harga yang ditawarkan & & & 1.16 & \\
\hline 7 & $\begin{array}{l}\text { Kerapihan plastik pengemasan untuk mengirim } \\
\text { produk }\end{array}$ & & \multirow{7}{*}{ IV } & -2.51 & \multirow{7}{*}{6} \\
\hline 18 & Pengetahuan pegawai tentang produk & & & -0.11 & \\
\hline 1 & $\begin{array}{l}\text { Variasi jenis produk yang ditawarkan (Dress, } \\
\text { rok, sweater, baju atasan) }\end{array}$ & & & 1.01 & \\
\hline 3 & Variasi warna yang ditawarkan & & & 2.75 & \\
\hline 23 & $\begin{array}{l}\text { Kecepatan pengembalian uang jika barang } \\
\text { ternyata habis }\end{array}$ & & & 3.62 & \\
\hline 2 & Variasi model produk yang ditawarkan & & & 3.73 & \\
\hline 30 & Tampilan media sosial yang menarik & & & 4.60 & \\
\hline
\end{tabular}

\section{Kesimpulan dan Saran}

- Agar CDCmodels dapat meningkatkan penjualan dan memenangkan persaingan dengan onlineshop pakaian lainnya, dilakukan penelitian menggunakan variabel pemasaran dengan bauran pemasaran $4 \mathrm{P}$ dari E-commerce and E-business (Gary, 2012)

- Target pasar yang diusulkan berdasarkan hasil penelitian adalah konsumen wanita berusia 19-47 tahun, mengetahui CDCmodels dari media sosial, sering menggunakan Instagram, menyukai model pakaian dengan fashion terkini, lebih mengutamakan harga dan model/desain dalam membeli pakaian, membeli semua jenis pakaian (baju atasan, jaket, sweater, dress), membeli pakaian sebanyak 2 kali dalam 1 bulan dengan kisaran harga $<\mathrm{Rp}$ 150.000 , mencari informasi yang jelas tentang pakaian sebelum membeli.

- Positioning statement yang diusulkan agar CDCmodels ada di benak konsumen saat berbelanja di onlinestore pakaian adalah "GUES\$ = Good, Unique, Safe":

- Prioritas usulan ditentukan berdasarkan hasil pengolahan Corresspondence Analysis, Importance Performance Analysis dan pengujian hipotesis rata-rata, dilengkapi dengan profil konsumen yang didapatkan dari kuesioner penelitian yaitu :

o Prioritas 1 :

1) Kelengkapan ukuran: saat ini ukuran dari setiap model pakaian yang dijual di CDCmodels adalah one size, sebaiknya CDCmodels mulai menjual produk pakaian yang memiliki berbagai ukuran dan mencantumkan spesifikasi ukuran secara rinci.

2) Detail foto produk yang jelas (tampak depan, belakang): sesuai keinginan konsumen, CDCmodels perlu menampilkan foto produk dari bagian depan-belakang-samping dengan pencahayaan, warna dan kontras yang berkualitas, membuat katalog produk yang rapih dan menarik, serta menampilkan detail foto (bahan, bordiran, jahitan dan sablonan).

3) Info tentang produk baru yang dikeluarkan: saat ini produk baru hanya diinformasikan melalui Instagram dan BBM saja. 50\% dari konsumen mengetahui CDCmodels dari media sosial oleh karena itu sebaiknya CDCmodels selalu mengupdate mengenai 
produk yang baru dikeluarkan di setiap media sosial beserta keterangan harga, bahan dan ukuran.

4) Jaminan atau masa garansi terhadap produk : saat ini CDCmodels hanya memberi waktu masa garansi 3 hari setelah barang diterima. Disarankan agar CDCmodels menjamin proses retur bahkan refund jika kesalahan terjadi dari pihak CDCmodels, melakukan pemeriksaan detail (kerapihan jahitan, bahan, sablonan dan bordiran), memproses retur dan refund berlaku berdasarkan peraturan yang sudah dibuat (pengembalian produk dapat dilakukan max 1 minggu produk diterima konsumen, penggantian produk cacat dengan produk baru dan seluruh biaya penukaran ditanggung oleh CDCmodels, proses refund apabila produk yang dipesan tidak sesuai deskripsi produk).

o Prioritas 2

1) Kecepatan respon pegawai kepada konsumen: memberikan jaringan wifi yang baik kepada pegawai agar proses transaksi berjalan dengan lancar dan menambahkan admin baru.

2) Kejelasan info tentang baju yang tersedia: saat ini CDCmodels tidak mempunyai halaman yang menunjukan ketersediaan stock, sehingga konsumen harus menanyakan terlebih dahulu kepada admin tentang stock yang tersedia. CDCmodels disarankan untuk membuat halaman di website tentang stock baju yang tersedia, juga menginformasikannya di media sosial.

3) Keluasan jangkauan penjualan toko online (nasional, internasional): hingga saat ini CDCmodels hanya melakukan pengiriman di dalam negeri saja dan tidak menerima pengiriman sampai luar negeri. CDCmodels disarankan untuk membuat website dengan domain.com agar mudah diakses oleh semua orang di dunia, menerima pengiriman menggunakan jasa ekspedisi DHL, Fedex, UPS \& EMS, serta memperluas jaringan resseler di Instagram dengan semua pengguna Instagram.

$\circ$ Prioritas 3

1) Kemenarikan program diskon yang diberikan setiap bulan: CDCmodels hanya memberikan diskon untuk produk lama. 27\% dari responden membeli pakaian dengan mempertimbangkan harga, sehingga sebaiknya CDCmodels memberi diskon khusus jika membeli produk dengan jumlah tertentu dalam satu kali transaksi dan membuka peluang konsumen menjadi reseller CDCmodels agar mendapatkan harga lebih murah.

2) Tampilan iklan yang menarik di sosial media: CDCmodels hanya menampilkan video dan foto paket pengiriman di Instagram. CDCmodels disarankan untuk memasang iklan-iklan pada setiap media sosial, karena $50 \%$ dari responden mengetahui CDCmodels dari media sosial, lengkap dengan slogan GUES\$ (Good, Unique, Safe) disetiap iklan agar menarik perhatian konsumen.

3) Kejelasan akan keberadaan produk yang telah dibeli konsumen: saat ini CDCmodels tidak pernah update tentang keberadaan produk, hanya memberikan nomor resi pengiriman barang jika diminta oleh konsumen saja. CDCmodels disarankan untuk memberitahu nomor resi pengiriman beserta cara tracking melalui masing-masing jasa pengiriman yang dipilih, agar konsumen dapat melacak posisi produk yang dipesan.

4) Kemudahan mencari info tentang toko online: saat ini media sosial CDCmodels hanya Instagram, sebaiknya CDCmodels menambahkan hastag di Instagram seperti \#pakaianwanita \#sweater \#jaket \#bajuatasan \#dress untuk mempermudah konsumen. Selain Instagram, CDCmodels juga disarankan menggunakan semua media sosial agar mudah ditemukan oleh konsumen.

\section{○ Prioritas 4}

1) Harga yang ditawarkan sesuai dengan kualitas produk: $27 \%$ dari responden membeli pakaian dengan mempertimbangkan harga oleh karena itu sebaiknya CDCmodels memberikan harga produk yang tidak terlalu tinggi dan menjual produk dengan kualitas yang lebih baik. 
2) Kemenarikan program diskon yang diberikan kepada konsumen setiap hari raya: saat ini CDCmodels hanya memberikan sale $10 \%$ pada setiap hari raya. CDCmodels disarankan untuk membuat program diskon hari raya yang lebih menarik dan membuat produk sendiri sehingga dapat memberikan diskon lebih besar.

- Usulan Pembuatan Website

CDCmodels disarankan untuk membuat web tersendiri, dengan tujuan:

1) Mempromosikan usaha CDCmodels melalui web, dengan cara:

- Mempromosikan nama CDCmodels, produk yang dijual, pelayanan, harga yang ditawarkan terhadap konsumen.

- Penjualan produk dapat dilakukan selama 24 jam non stop

2) Dapat memperbaiki sistem customer service, dengan cara menyediakan informasi lengkap tentang deskripsi produk, daftar harga, kejelasan stock, progress pemesanan barang dan informasi tambahan langsung dari Website.

3) Menyediakan testimonial konsumen yang menggambarkan bagaimana pendapat konsumen lain setelah berbelanja produk CDCmodels di website, menerima produk serta pelayanan yang diberikan.

- Dalam pembuatan website, perlu diperhatikan aspek berikut :

- Content, terdiri dari content spesifikasi CDCmodels (nama, nomor telepon, alamat, email, dan sebagainya), deskripsi produk, ilustrasi, spesifikasi, instruksi pembelian, instruksi pengiriman, katalog pakaian dan testimonial konsumen.

- Aspek desain, terdiri dari warna, layout yang menarik, web yang mudah dan cepat, link yang inovatif.

- Fungsional, meliputi keamanan penggunaan web, shopping chart tertata dengan rapih menurut kategorinya, fitur yang ramah, slide foto berjalan dan pembelian produk yang dapat langsung diakses di website

- Beberapa tampilan Desain web CDCmodels untuk konsumen:

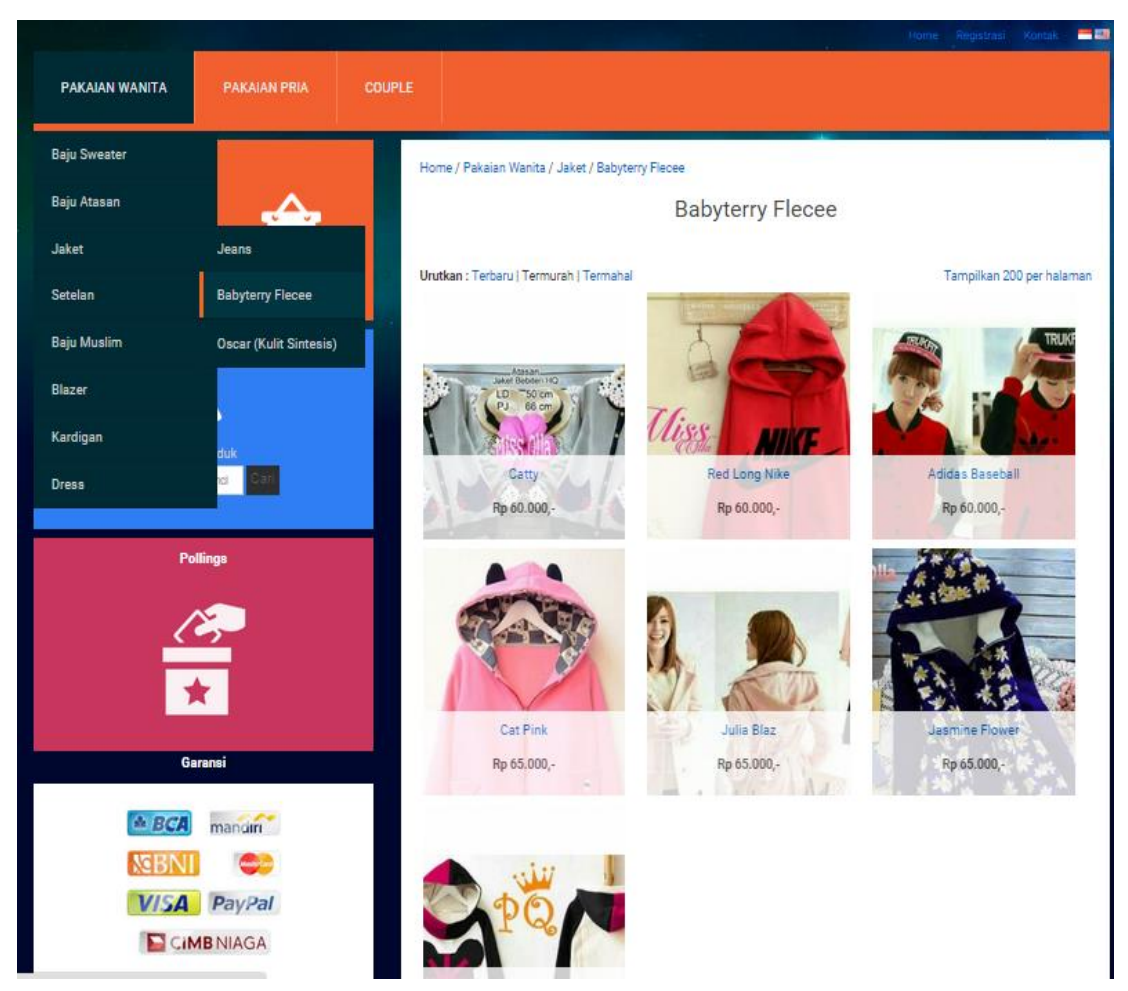

Gambar 5. Katalog Pakaian Perempuan Website CDCmodels 


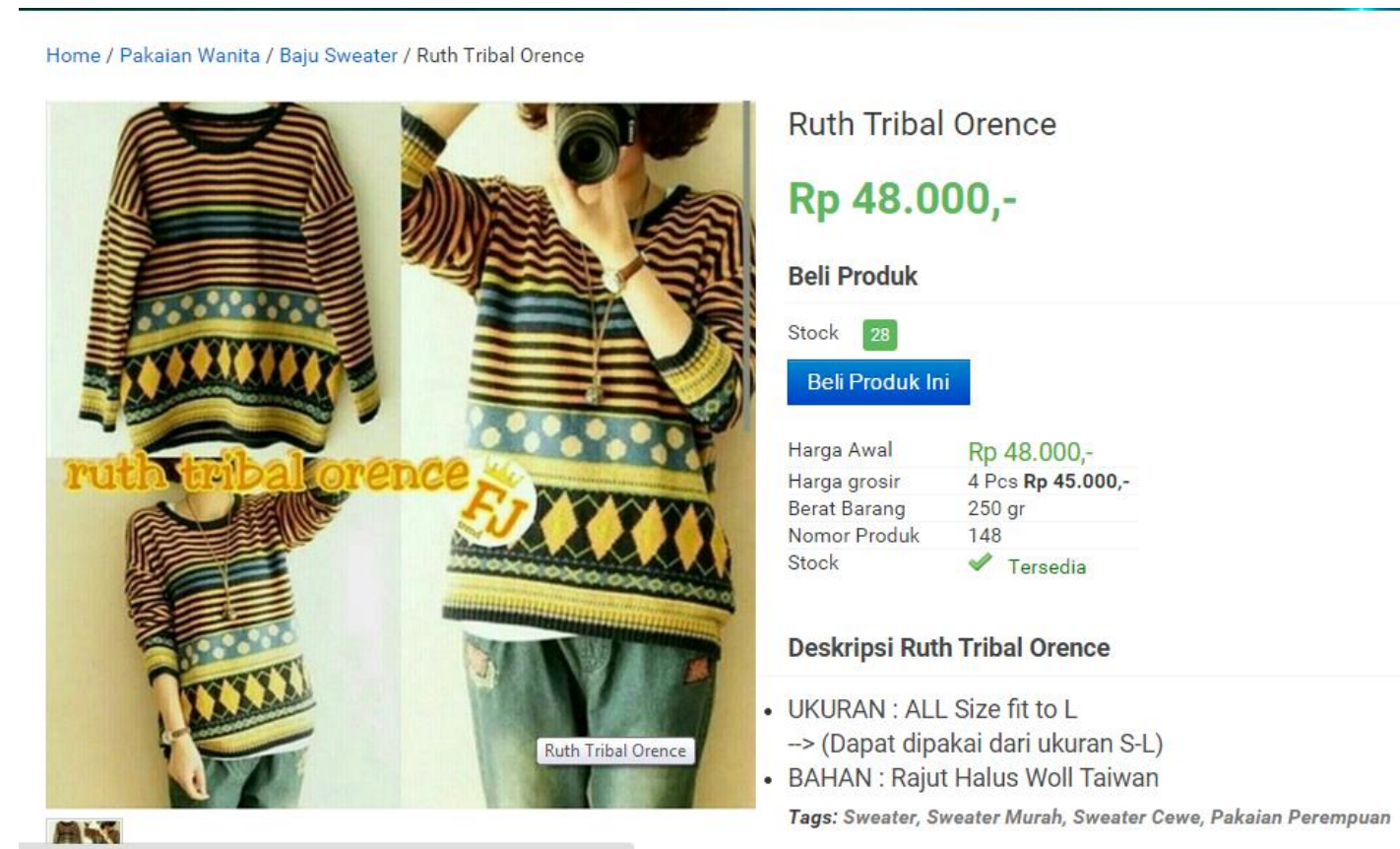

Gambar 6. Detail Produk

CARA BELANJA

Untuk berbelanja diwebsite kami ikuti panduan dibawah ini, bila anda masih menemukan kesulitan dalam berbelanja jangan ragu untuk menghubungi customer care kami atau isi form dihalaman

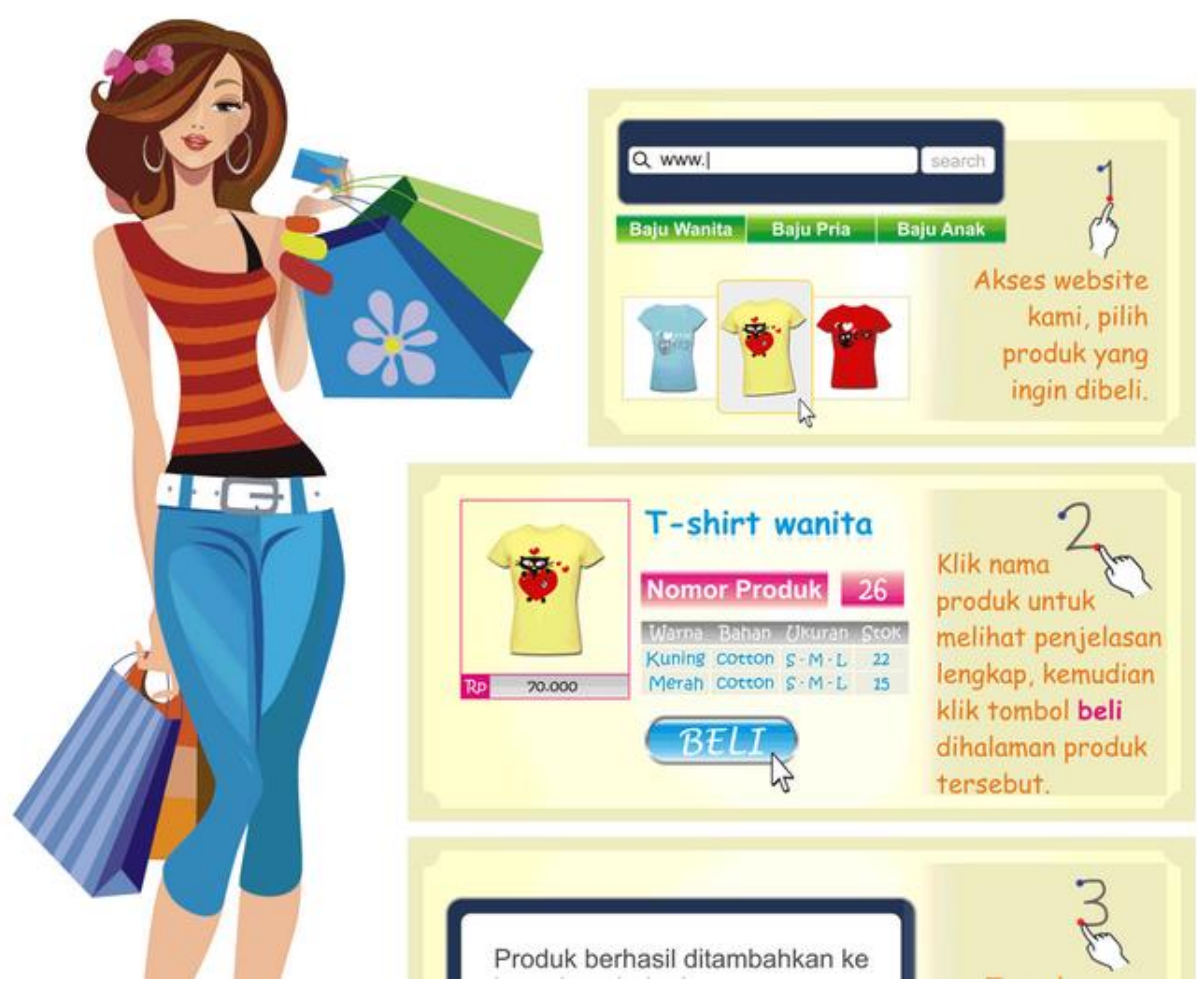

Gambar 7. Informasi Cara Belanja 
JOURNAL OF INTEGRATED SYSTEM VOL 1. NO. 1, JUNI 2018: 105-127

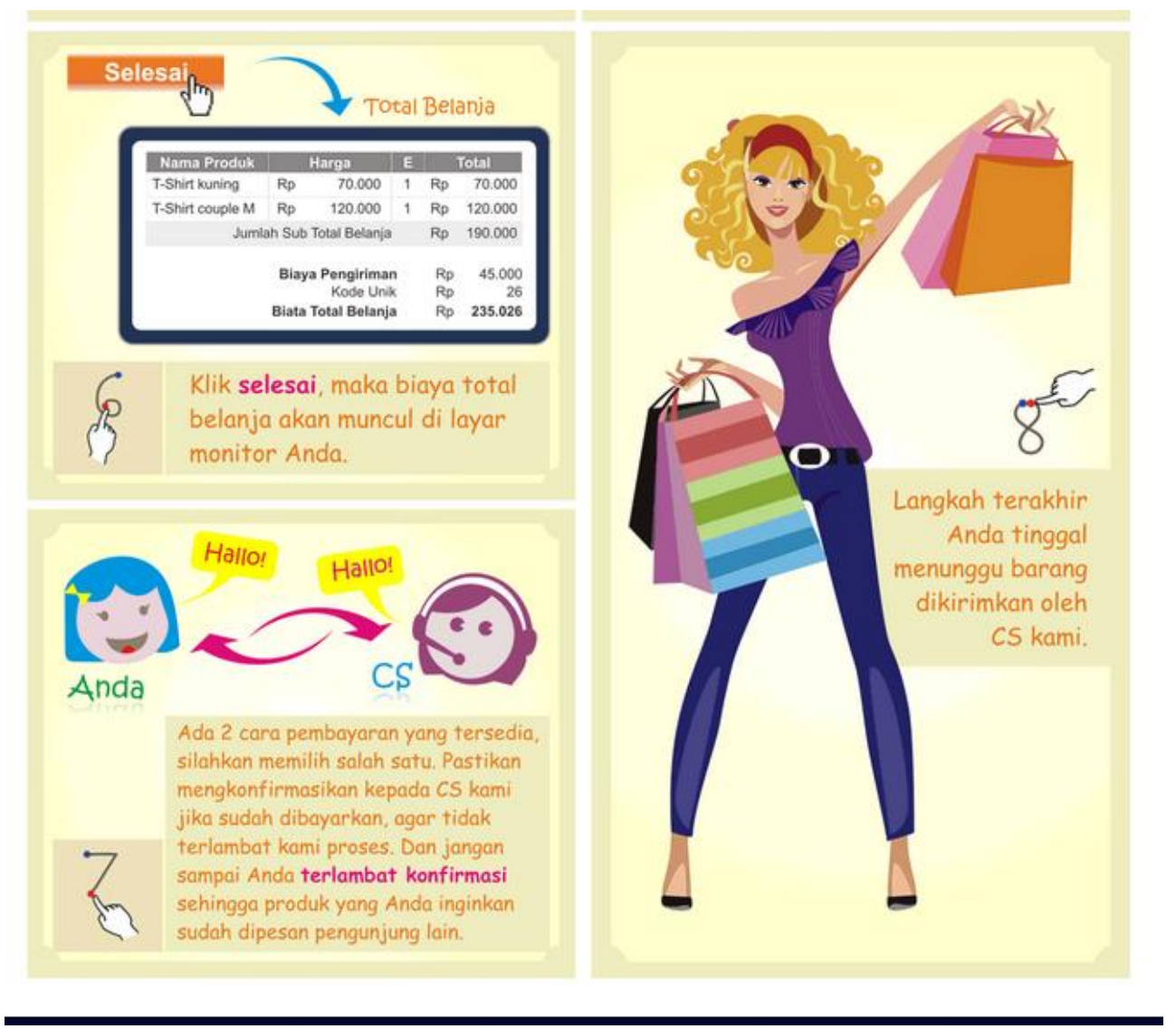

Gambar 7. Informasi Cara Belanja (Lanjutan)

Home / Cara Pembayaran

CARA PEMBAYARAN

Anda bisa melakukan pembayaran produk kami dengan sistem transfer bank atau paypal.

Setelah melakukan transfer, silahkan konfirmasi melalui menu konfirmasi member yang tersedia, atau bisa melalui chat, email, sms, telpon, BBM, LINE

Berikut daftar bank yang bisa digunakan untuk transfer

BNI : 0207545394

BRI : :1070-01-007355-50-7

BCA : : 1571483357

MANDIRI : $900-00-2686726-8$

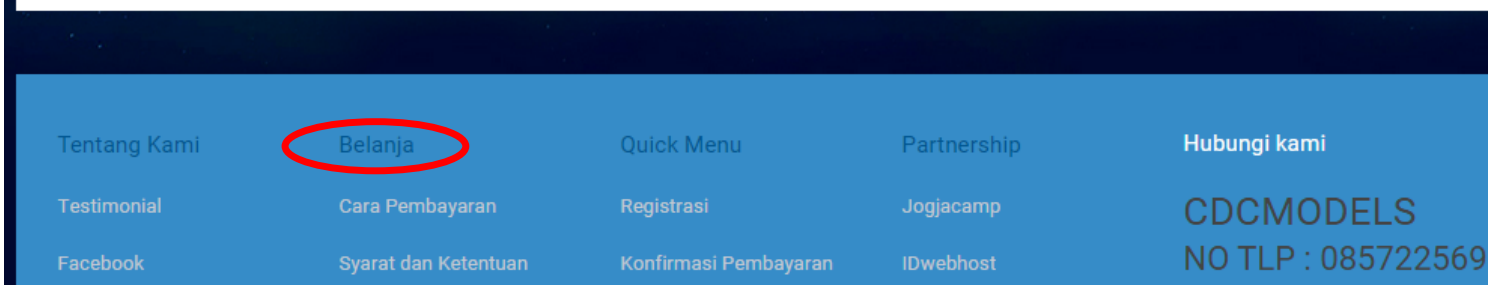

Gambar 8. Informasi Cara Pembayaran 


\section{USULAN STRATEGI PEMASARAN ONLINESHOP (Christine D.H., dkk)}

STATUS ORDER

Order Terkini

\begin{tabular}{|c|c|c|}
\hline Order & \multicolumn{2}{|l|}{06 Apr 2015 ( Rp 48.000,- ) } \\
\hline Status & \multicolumn{2}{|l|}{ BELUM DIBAYAR } \\
\hline Detail Status & \multicolumn{2}{|l|}{ Order Anda Belum dibayar pada 06 APR 2015} \\
\hline Produk & 451 pCs RUTH TRIBAL ORENCE & Rp 48.000,- \\
\hline \multirow[t]{4}{*}{ Biaya } & Biaya Produk & Rp 48.000; \\
\hline & Ongkos Kirim & Rp 6.000; \\
\hline & Biaya Tambahan & $\mathrm{RpO}^{-}$ \\
\hline & Total Biaya & RP 54.000,- \\
\hline \multirow[t]{4}{*}{ Pengiriman } & Nama & Christine Dwi \\
\hline & Alamat & Jl. Bojong Raya \\
\hline & & $\begin{array}{l}\text { BANDUNG KULON,BANDUNG, BANDUNG Jawa } \\
\text { Barat, } 40212\end{array}$ \\
\hline & Ekspedisi & JNE REG \\
\hline
\end{tabular}

Order Sebelumnya

\begin{tabular}{llllll} 
Total Biaya & Tgl Order & Pembayaran & Dikirim & Status & Detail \\
\hline Rp 54.000,- & 06 Apr 2015 & & Sudah Konfirmasi & Lihat Detail \\
\hline Rp 66.000,- & 05 Apr 2015 & 06 Apr 2015 & 06 Apr 2015 & Terkirim & Lihat Detail
\end{tabular}

Gambar 9. Informasi untuk Status Order

- Beberapa tampilan Desain web CDCmodels untuk pihak perusahaan:

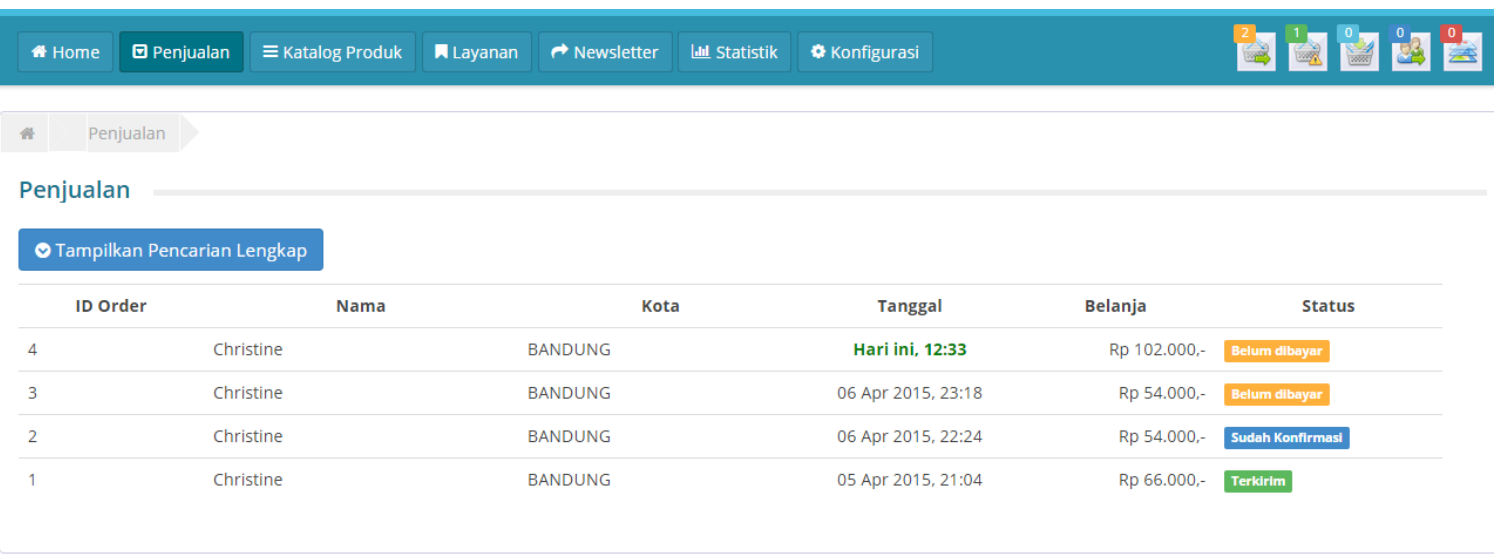

Gambar 10. Order Barang 
JOURNAL OF INTEGRATED SYSTEM VOL 1. NO. 1, JUNI 2018: 105-127
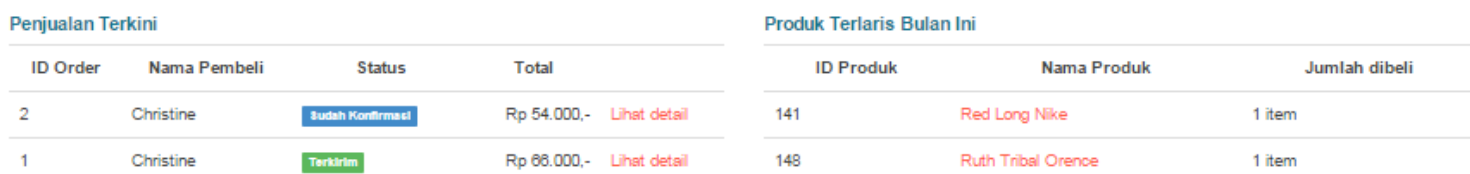

\begin{tabular}{|c|c|c|}
\hline ID Produk & Nama Produk & Dilihat \\
\hline 112 & Set Popular Girl & 8 kali \\
\hline 113 & Keiko Set & 8 kali \\
\hline 178 & 68 Hooker & 7 kali \\
\hline 148 & Ruth Tribal Orence & $6 \mathrm{kali}$ \\
\hline 177 & Scarlet Dress & 4 kali \\
\hline
\end{tabular}

\begin{tabular}{ll} 
Rangkuman Bulan Ini & Rp 68.000,- \\
\hline Penjualan & 1 \\
\hline Order terkirim & 1 orang \\
\hline Member baru & 0 \\
\hline Member newsletter baru & $82 \mathrm{kgli}$
\end{tabular}

Gambar 11. Rangkuman Penjualan

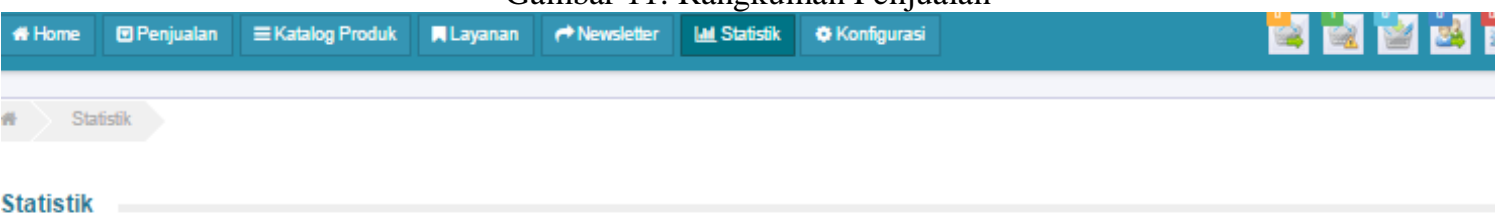

6 March, 2015- 6 Aprll, 2015
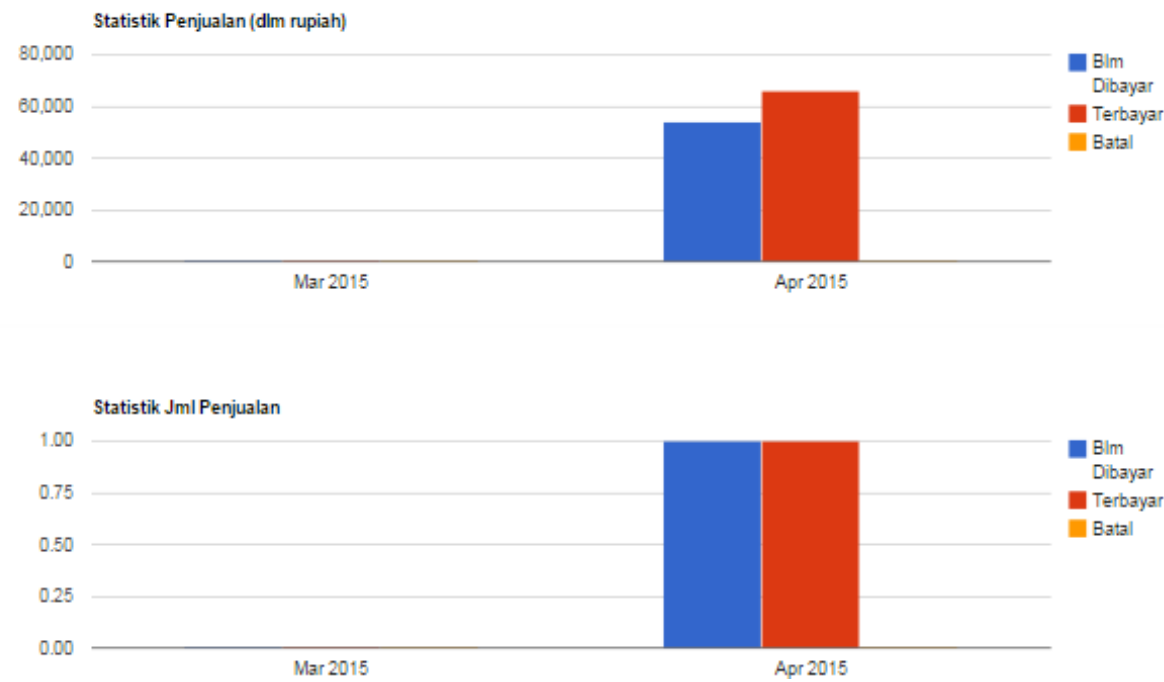

Gambar 12. Data Statistik Penjualan

\section{Daftar Pustaka}

Aaker, Myers., (1995), Advertising Management, Prentice Hall of India, Private Ltd.

Anandya, Dudy, Suprihadi, H., (2009), Riset Pemasaran Prospektif dan Terapan, Bayumedia Publishing, Malang

Anderson, D., Sweeney, D.J., Williams, T.A., (2008), Statistics for Business \& Economics, $10^{\text {th }}$ edition, Thomson South-Western

Gary, Schneider., (2012), Introduction to E-Business, edisi 10, CENGAGE Learning, Phillipine. 


\section{USULAN STRATEGI PEMASARAN ONLINESHOP (Christine D.H., dkk)}

Hair, Anderson, Tatham \& Black, (2006), Multivariate Data Analysis, Prentice-Hall International, Inc., USA

Kasali, Rhenald, (2001), Membidik Pasar Indonesia Segmentasi, Targeting, Positioning, PT Gramedia Pustaka Utama, Jakarta.

Kotler, P., (1997), Marketing Management: Analysis, Planning, Implementation and Control, $9^{\text {th }}$ edition, Prentice Hall Inc., New Jersey

Kotler, P., Keller, K., (2007), Manajemen Pemasaran, Jilid 1, Edisi Ke-12, diterjemahkan oleh Benyamin Molan, PT. Macanan Jaya Cemerlang, Indonesia

Misbahuddin, Hasan, I., (2013), Analisis Data Penelitian dengan Statistik, edisi Ke-2, PT Bumi Aksara, Jakarta

Rangkuti, Freddy; (2002), Riset Pemasaran, PT. Gramedia Pustaka Utama, Jakarta

Sugiyono, (2010), Metode Penelitian Administrasi, CV. ALFABETA, Bandung

Supranto, J., (2001), Pengukuran Tingkat Kepuasan Pelanggan., PT Rineka Cipta, Jakarta 